\title{
Meningkatkan Kompetensi Profesional Guru Melalui Kegiatan Supervisi Akademik Pada MA Al-Mubarak Marisa
}

\author{
Ismiati Ahmad \\ Kepala MA Al-Mubarak Marisa \\ ismiati@gmail.com \\ Received: 04 March 2021; Revised: 26 April 2021; Accepted: 28 August 2021 \\ DOI: http://dx.doi.org/10.37905/aksara.7.3.1123-1134.2021
}

\begin{abstract}
ABSTRAK:
Tujuan dari penelitian ini adalah untuk mengetahui peningkatan kompetensi guru melalui kegiatan Supervisi di MA Al-Mubarak Marisa Kabupaten Pohuwato. Hal ini dapat dibuktikan dengan melalui hasil penilaian pelaksanaan pembelajaran pada siklus I mencapai nilai rata-rata 71,35 termasuk dalam kategori baik, kemudian pada siklus II mencapai nilai rata-rata 83,70 termasuk dalam kategori baik. Dengan demikian terjadi peningkatan pelaksanaan pembelajaran sebesar 12,35 \%. Guru MA Al-Mubarak Marisa Kabupaten Pohuwato setelah disupervisi melalui kunjungan kelas pra pembelajran yaitu kemampuan menyusun perencanaan pembelajaran yang sekaligus dapat mengalami peningkatan kemampuan melaksanakan pembelajaran. Peningkatan kemampuan guru tersebut dapat dibuktikan dari hasil penilaian pra pembelajaran pra siklus menunjukkan rata-rata 68,82 dan pada siklus I meningkat sebesar $11,96 \%$ dengan nilai rata-rata 80,78 , kemudian pada siklus II meningkat lagi sebesar 10,38 \% menjadi 91,17 dengan kategori sangat baik. Peningkatan kemampuan guru dalam pra pembelajaran/perencanaan pembelajaran tersebut sekaligus diikuti dengan peningkatan kemampuan guru dalam melaksanakan pembelajaran pada siklus I mencapai nilai sebesar 71,35 dan pada siklus II mencapai nilai rata-rata sebesar 83,70, maka terjadi peningkatan sebesar 12,35\%. Dengan demikain dapat disimpulkan bahwa melalui kegiatan Supervisi dengan kunjungan kelas dan meningkatakan profesionalisme guru dalam melaksanakan pra pembelajaran/perencanaan pembelajaran dan dapat mengingkatkan kemampuan melaksanakan pembelajaran di MA Al-Mubarak Marisa Kabupaten Pohuwato.
\end{abstract}

Kata Kunci: manajemen, perencanaan, pelaksanaan, evaluasi, kepala sekolah dan kompetensi professional guru.

\section{PENDAHULUAN}

Dalam hal ini, kompetensi diartikan sebagai pengetahuan, keterampilan, dan kemampuan yang dikuasai oleh seseorang yang telah menjadi bagian dari dirinya, sehingga ia dapat melakukan perilaku-perilaku kognitif, afektif, dan psikomotorik dengan sebaik-baiknya

Sebagaimana telah dimaklumi bahwa dalam lingkup pendidikan yang terkecil yaitu sekolah, guru memegang peranan yang amat penting dan strategis. Kelancaran proses seluruh kegiatan pendidikan terutama disekolah, sepenuhnya berada dalam tanggung jawab para guru. Guru adalah seorang pemimpin yang harus mengatur, 
mengawasi dan mengelola seluruh kegiatan proses pembelajaran di sekolah yang menjadi lingkup tanggung jawabnya

Dalam menghadapi tuntunan situasi perkembangan zaman dan pembangunan nasional, sistem pendidikan nasional harus dapat dilaksanakan secara tepat guna dan hasil guna dalam berbagai aspek dimensi,jenjang dan tingkat pendidikan. Keadaan semacam itu pada gilirannya akan menuntut para pelaksana dalam bidang pendidikan diberbagai jenjang untuk mampu menjawab tuntutan tersebut melalui fungsi-fungsinya sebagai guru.

Guru memegang peranan yang sangat penting dan strategis dalam upaya membentuk watak bangsa dan mengembangkan potensi siswa dalam kerangka pembangunan pendidikan di Indonesia. Tampaknya kehadiran guru hingga saat ini bahkan sampai akhir hayat nanti tidak akan pernah dapat digantikan oleh yang lain, terlebih pada masyarakat Indonesia yang multikultural dan multibudaya, kehadiran teknologi tidak dapat menggantikan tugas-tugas guru yang cukup kompleks dan unik. Oleh sebab itu, diperlukan guru yang memiliki kemampuan yang maksimal untuk mewujudkan tujuan pendidikan nasional dan diharapkan secara berkesinambungan mereka dapat meningkatkan kompetensinya, baik kompetensi pedagogik, kepribadian, sosial, maupun profesional. Profesional artinya dilaksanakan secara sungguh- sungguh dan didukung oleh para petugas secara profesional. Petugas yang profesional adalah petugas yang memiliki keahlian, tanggung jawab, dan rasa kesejawatan yang didukung oleh etika profesi yanng kuat. Untuk menguji kompetensi tersebut, pemerintah menerapkan sertifikasi bagi guru khususnya guru dalam jabatan. Penilaian sertifikasi dilakukan secara portofolio

Sejumlah penelitian membuktikan bahwa guru yang profesional merupakan salah satu indikator penting dari sekolah berkualitas. Guru yang profesional akan sangat membantu proses pencapaian visi misi sekolah. Mengingat strategisnya peran yang dimiliki oleh seorang guru, usaha-usaha untuk mengenali dan mengembangkan profesionalisme guru menjadi sangat penting untuk dilakukan.

Masalahnya yang penting adalah mengapa guru itu dikatakan sebagai pendidik. Guru memang seorang pendidik, sebab dalam pekerjaannya ia tidak hanya mengajar seseorang agar tahu beberapa hal, tetapi guru juga mengalihkan beberapa keterampilan dan terutama sikap mental anak didik. Mendidik sikap mental seseotan tidak cukup hanya mengajar sesuatu pengetahuan tetapi bagaimana pengetahuan itu harus dididikkan/diajarkan, dengan guru sebagai idolanya.

Minat, bakat, kemampuan, dan potensi peserta didik tidak akan berkembang secara optimal tanpa bantuan guru. Dalam kaitan ini guru perlu memperhatikan peserta didik secara individual. Tuga guru tidak hanya mengajar, namun juga mendidik, mengasuh, membimbing, dan membentuk kepribadian siswa guna menyiapkan dan mengembangkan sumber daya manusia (SDM).

Dengan mendidik dan menanamkan nilai-nilai yang terkandung pada berbagai pengetahuan yang dibarengi dengan contoh-contoh teladan dari sikap dan tingkah laku gurunya, diharapkan anak didik/siswa dapat menghayati dan kemudian miliknya, sehingga dapat menumbuhkan sikap mental. Jadi tugas seorang guru bukan sekedar menumpahkan semua ilmu pengetahuan tetapi juga mendidik seseorang menjadi warga negara yang baik, menjadi seseorang yang berperilaku baik dan utuh. Mendidik berarti mentransfer nilai-nilai kepada siswanya. Nilai-nilai tersebut harus diwujudkan dalam tingkah laku sehari-hari. 
Dunia pendidikan yang seharusnya penuh dengan kasih sayang, tempat untuk belajar dengan moral, budi pekerti justru sekarang ini dekat dnegan tindak kekerasan dan asusila. Dunia pendidikan seharusnya mencerminkan sikap-sikap intelektual, budi pekerti, dan menjunjung tinggi nilai moral, justru telah dicoreng oleh segelintir oknum pendidikan (guru) yang tidak bertanggung jawab. Realitas ini mengandung pesan bahwa dunia pendidikanharus segera melakukan evaluasi ke dalam. Sepertinya, sudah waktunya untuk melakukan pelurusan kembali atas pemahakan dalam memposisikan profesi guru.

Kesalahan guru dalam memahami profesinya akan mengakibatkan bergesernya fungsi guru secara perlahan-lahan. Pergeseran ini telah menyebabkan dua pihak yang tadinya sama-sama membawa kepentingan dan salingmembutuhkan, yakni guru dan siswa, menjadi tidak lagi saling membutuhkan. Akibatnya suasana belajar sangat memberatkan, membosankan,dan jauh dari suasana yang membahagiakan. Dari sinilah konflik demi konflik muncul sehingga pihak-pihak di dalamnya mudah frustasi lantas mudah melampiaskan kegundahannya dengan cara-cara yang tidak benar.

Guru masa depan bangsa kita, masyarakat kita, sangat membutuhkan para guruguru yang mampu mengangkat citra pendidikan kita terkesan sudah carut-marut, dan seperti benang kusut. Sehingga bagaimana harus dimulai, kapan dan siapa yang memulainya, dan dari mana harus dimulai. Jika kita masing-masing menyadari, memiliki rasa kepedulian, mau berbagi rasa, atau kalaulah mau kita ber-tepo seliro, maka pendidikan kita seperti disebutkan di atas, akan dapat dianulir. Oleh sebab itu semua ktia memiliki satu persepsi, satu langkah dan satu tujuan sebagaimana kita berusaha mengangkat citra pendidikan tersebut, menjadi pendidikan bermutu, dan tentunya diharapkan mampu untuk mengangkat peringkat dan citra pendidikan termasuk terendah di Asia.

Kepribadian guru mampu mempunyai pengaruh langsung dan kumulatif terhadap hidup dan kebiasaan-kebiasaan belajar para siswa. Yang dimaksud dengan kepribadian di sini meliputi pengetahuan, keterampilan, ideal, sikap, dan juga persepsi yang dimilikinya tentang orang lain. Para siswa menyerap sikap-sikap gurunya, merefleksikan perasaan-perasaannya, meniru tingkah lakunya dan mengutip pengetahuan-pengetahuannya.

Satu hal yang akan menjadi titik perhatian kita adalah "bagaimana merancang guru masa depan yang menjadi teladan”. Guru masa depan adalah guru yang memiliki kemampuan, dan keterampilan bagaimana dapat menciptakan hasil pembelajaran secara optimal, selanjutnya memiliki kepekaan di dalam membaca tanda-tanda zaman, serta memiliki wawasan intelektual dan berpikiran maju, tidak pernah merasa puas dengan ilmu pengetahuan yang ada padanya.

Sesuai dengan perkembangan masyarakat dan perkembangan pendidikan di negara kita, maka paradigma tenaga pendidikan pun sudah seharusnya mengalami perubahan pula, khususnya yang berkaitan dengan supervisi atau kepengawasan pendidikan ini. Dengan paradigma lama tergambar bahwa kegiatan tidak dapat diharapkan berjalan lancar dengan sendirinya sesuai dengan rencana dan tujuan yang telah ditetapkan, jika tidak diawasi. Apa yang diharapkan untuk dikerjakan seseorang atau sekelompok orang, seringkali kurang bahkan tidak dilakukan, bukan karena tidak mau atau tidak mengerti, tetapi karena tidak ada orang yang mengawasi. Jadi peran pengawas saat ini sangat dominan. Dengan pengawasan seperti ini pula diharapkan suatu rencana kegiatan dapat terlaksana sesuai dengan garis yang ditetapkan. 
Berdasarkan gambaran tersebut dapat dipahami bahwa pengawasan cenderung bersifat otokratis, mencari-cari kesalahan atau kelemahan orang lain dan berorientasi pada kekuasaan dan kekuatan. Pengertian pengawasan seperti ini sering disebut inspeksi atau memeriksa, orang yang melakukan pemeriksaan itu sendiri disebut inspektur.

Perubahan demi perubahan telah dialami dan dilalui. Demikian pula pengertian pengawasan seperti di atas lambat laun mengalami perubahan pula. Perubahanperubahan barat mulai masuk, sehingga pengertian pengawasn dalam pendidikan diubah menjadi supervisi yang maksudnya hampir sama dengan inspeksi, tetapi istilah supervisi mengandung pengertian yang lebih luas dan lebih demokratis, tidak hanya melihat apakah kepala sekolah, guru, dan pegawai sekolah telah melakukan tugas dan kegiatan sesuai dengan pedoman yang ada, akan tetapi juga berusaha mencari jalan keluar bagaimana cara perbaikannya. Para supervisor pun berkewajiban memberikan bimbingan, pembinaan, dan petunjuk-petunjuk yang diperlukan. Hubungan antara pengawas/supervisor dengan yang diawasi lebih bersifat kemitraan, hubungan komunikasi pun tidak lagi one way traffic tetapi two way traffic.

Dengan paradigma baru ini diharapkan para pendidik dan para supervisor dapat menjalin kerjasama yang lebih harmonis dalam rangka mengemban tugas-tugas kependidikan yang dibebankan kepada diri masing-masing. Dengan harapan guru dapat menjalankan tugas secara profesional sesuai dengan tugas, fungsi, dan tanggung jawabnya.

\section{METODE PENELITIAN}

Penelitian ini dilaksanakan di MA Al-Mubarak Marisa Kabupaten Pohuwato. Berdasarkan waktu yang telah ditentukan serta instrumen pengamatan (observasi pelaksanaan supervisi) yang telah disiapkan, peneliti segera melaksanakan tindakan dengan dibantu oleh Guru-guru MA Al-Mubarak Marisa Kabupaten Pohuwato dan guru sebagai observator

Jenis penelitian yang dilakukan oleh peneliti yaitu penelitian tindakan sekolah yang lazim disebut PTS. Dengan demikian penelitian ini sifatnya berbasis sekolah karena dilakukan dengan melibatkan komponen yang terdapat di dalam penyelenggaraan pembelajaran di sekolah meliputi: guru, siswa, materi pembelajaran, dan teknik pembelajaran.

Tujuan penelitian ini tidak lain adalah untuk meningkatkan kemampuan/sikap profesionalisme guru dalam melaksanakan pembelajran. Diharapkan dari penelitian ini kemampuan guru dalam melaksanakan pembelajaran dapat meningkatkan yang pada akhirnya dapat berdampak pada peningkatan hasil belajar secara maksimal. Terdapat empat tahapan yang digunakan secara sistematis dalam proses penelitian ini dan diterapkan dalam dua siklus yaitu siklus I dan proses tindakan siklus II

Proses penelitian tindakan sekolah dalam siklus I terdiri atas empat tahap, yaitu perencanaan, tindakan, pengamatan, dan refleksi Proses tindakan siklus II merupakan kelanjutan dari siklus I. Perbaikan pada proses kunjungan kelas dan proses pembelajaran agar lebih serius lagi dan lebih ditingkatkan. Langkah-langkah siklus II adalah perencanaan, tindakan, pengamatan, dan refleksi.

Teknik pengumpulan data yang digunakan adalah penilaian yang dilakukan sebanyak dua kali, yaitu siklus I dan siklus II. Bentuk penilaiannya adalah penilaian 
terhadap pra pembelajran, dan penilaian terhadap pelaksanaan pembelajaran di kelas. Penilaian diberikan kepada guru kelas MA Al-Mubarak Marisa Kabupaten Pohuwato.

Target tingkat keberhasilan guru ditetapkan jika guru dapat melaksanakan pembelajaran dalam kategori baik, sesuai dengan rencana pelaksanaan pembelajaran yang telah disusun. Di samping teknik yagn digunakan untuk mengamati aktivitas guru kelas dan siswa dalam proses pembelajaran, dengan cara memberi tanda cek (ï) pada lembar observasi.

\section{HASIL DAN PEMBAHASAN \\ Kondisi Awal}

Kondisi awal merupakan keadaan sebelum tindakan dilaksanakan. Sebelum tindakan siklus I terlebih dahulu dilaksanakan pendataan awal terhadap persiapan pelaksanaan Supervisi. Dalam hal ini semua guru kelas mengumpulkan administrasi pengajaran/perangkat pembelajaran. Kemudian perangkat pembelajaran tersebut dinilai untuk mengetahui sejauh mana kemampuan awal guru kelas dalam mempersiapkan perangkat pembelajaran.

\section{Hasil Tindakan Pra Siklus}

Tindakan pra siklus yang dilakukan yaitu melaksanakan penilaian terhadap pembelajaran yang dibuat oleh guru kelas sebelum diadakan kunjungan kelas sebelum diadakan kunjungan kelas oleh supervisor. Penilaian tersebut meliputi rencana pelaksanaan pembelajaran, materi/bahan pengajaran, media pembelajaran, metode pembelajaran, dan penilaian.

Hasil yang diperoleh pada siklus pra siklus I menunjukkan bahwa kemampuan guru kelas di MA Al-Mubarak Marisa Kabupaten Pohuwato dalam persiapan pengajaran dalam kategori cukup dengan nilai rata-rata 68,82. Adapun rincian data dapat dijelaskan sebagai berikut: dari jumlah guru kelas ada $83 \%$ guru dalam kategori cukup dengan rentang nilai antara 55 - 74 dan $17 \%$ guru dalam kategori baik dengan rentang nilai antara 75 - 90 sedangkan untuk kategori sangat baik dengan rentang nilai 91 - 100 masih $0 \%$.

\section{Hasil Siklus I}

Hasil penilaian persiapan pembelajaran pada siklus I menunjukkan bahwa hasil penelitian kemampuan persiapan pembelajaran secara klasikal mencapai rata-rata 80,78 dengan kategori baik. Nilai rata-rata tersebut dapat dikatakan telah mengalami peningkatan sebesar 11,96 dari hasil pra siklus. Hasil penelitian pada siklus I sudah memenuhi target dalam kategori baik, namun belum pada nilai maksimal yaitu antara 91 - 100 sehingga diperlukan penilaian siklus II.

Dari jumlah guru tersebut belum ada yang meraih kategori sangat baik dengan nilai antara 91 - 100, kategori baik dengan nilai 75 - 90 diperoleh $83 \%$ guru dan $17 \%$ guru dalam kategori cukup baik dengan nilai antara $55-74$.

Hasil penilaian tersebut merupakan jumlah nilai 5 aspek penilaian persiapan pembelajaran, yaitu: (1) perumusan tujuan; (2) penjabaran materi; (3) alat/bahan pelajaran; (4) langkah-langkah PBM, dan (5) penilaian. Secara rinci hasil penilaian persiapan pembelajaran pada siklus I akan diuraikan pada tiap aspek penilaian persiapan pembelajaran. 
Hasil penilaian kemampuan melaksanakan pembelajaran secara kelompok mencapai rata-rata 71,35 dengan kategori cukup. Hasil penelitian pada siklus I belum dapat memenuhi target maksimal, yaitu nilai 91 - 100 sehingga perlu dilaksanakan penelitian siklus II. Dari 6 guru tersebut belum ada yang dapat meraih kategori sangat baik dengan nilai antara 91 - 100, kategori baik dengan nilai $75-90$ diperoleh $50 \%$ guru dan kategori cukup dengan nilai antara $55-74$ diperoleh $50 \%$ guru.

Belum maksimalnya hasil penilaian dikarenakan berbagai hal, antara lain kurangnya pengalaman mengajar, mengingat $50 \%$ dari jumlah guru yang ada merupakan guru yang belum pernah mengajar di tempat lain, di samping itu kondisi mental guru menurun pada saat dilakukan kunjungan kelas dalam penilaian pelaksanaan kunjungan pembelajaran.

Hasil penilaian tersebut merupakan jumlah penilaian 9 aspek penilaian pelaksanaan pembelajaran, yaitu: (1) pra pembelajaran; (2) pembukaan pembelajaran; (3) penguasaan materi pelajaran; (4) pendekatan/strategi pembelajaran; (5) pemanfaatan sumber belajar/media pembelajaran; (6) pembelajaran yang memicu dan memelihara keterlibatan siswa; (7) penilaian proses dan hasil belajar; (8) penggunaan bahasa, dan (9) menutup pelajaran. Hasil observasi dalam penelitian adalah pengamatan terhadap peneliti sekaligus sebagai supervisor dan guru sebagai yang disupervisi, yang dilakukan oleh supervisor sebagai pengamat. Pengambilan data obervasi dilakukan selama proses pelaksanaan kunjungan kelas di MA Al-Mubarak Marisa Kabupaten Pohuwato. Pengambilan data obervasi ini bertujuan untuk memotret aktivitas supervisor, guru kelas, dan siswa pada saat kunjungan kelas dilaksanakan.

Obyek sasaran yang diamati dalam observasi peneliti meliputi 9 perilaku yang muncul pada saat kunjungan kelas berlangsung. Adapun obyek sasaran observasi antara lain meliputi: (1) pra pembelajaran; (2) pembukaan pembelajaran; (3) penguasaan materi pelajaran; (4) pendekatan/strategi pembelajaran; (5) pemanfaatan sumber belajar/media pembelajaran; (6) pembelajaran yang memicu dan memelihara keterlibatan siswa; (7) penilaian proses dan hasil belajar; (8) penggunaan bahasa, dan (9) menutup pelajaran. Berdasarkan hasil pengamatn pelaksanaan kunjungan kelas di MA Al-Mubarak Marisa Kabupaten Pohuwato dalam kategori baik dengan skor nilai 80,66.

Dari hasil observasi pelaksanaan kunjungan kelas terlihat bahwa guru yang melakukan perilaku negatif yaitu guru yang sering meninggalkan kelas, ternyata dalam hasil penilaian mendapat nilai paling rendah sebesar 72,94 dalam kategori cukup, padahal guru yang lain mendapat nilai dalam kategori baik. Hal ini menunjukkan kurang tertib dalam pembelajaran secara langsung berpengaruh terhadap penilaian pembelajaran

\section{Hasil Siklus II}

Tindakan siklus II dilakukan karena pada siklus I kemampuan guru dalam melaksanakan pembelajaran di MA Al-Mubarak Marisa Kabupaten Pohuwato masih bermasuk dalam kategori cukup, belum memenuhi target maksinal nilai dalam kategori baik dengan rentang nilai antara 75 - 90. Selain itu dalam proses kegiatan pembelajaran masih ada perilaku-perilaku yang negatif baik guru maupun siswa, walaupun berdasarkan pengamatan bahwa pelaksanaan pembelajaran secara umum berjalan dengan baik.

Hasil penilaian pra pembelajaran/persiapan pembelajaran pada siklus II ini merupakan data kedua setelah dilakukannya perbaikan kegiatan pembelajaran dari siklus I, kriteria penilaian pada siklus II masih tetap sama seperti siklus I, yaitu meliputi: (1) 
perumusan tujuan; (2) penjabaran materi; (3) alat/bahan pelajaran; (4) langkah-langkah PBM, dan (5) penilaian.

Secara umum hasil penilaian pra pembelajaran menunjukkan bahwa hasil penilaian kemampuan merencanakan pembelajaran secara klasikal mencapai rata-rata 91,17 termasuk kategori sangat baik, berarti dapat menunjukkan bahwa kemampuan guru MA Al-Mubarak Marisa Kabupaten Pohuwato dalam pra/merencanakan pembelajaran berkategori sangat baik. Nilai rata-rata tersebut telah mengalami peningkatan sebesar 10,39 \%. Dari jumlah keseluruhan guru, 3 guru atau $50 \%$ dikategorikan sangat baik dengan rentang nilai antar 91 - 100, sedangkan 3 guru atau $50 \%$ termasuk dalam kategori baik dengan nilai antara 75 - 90. Hasil rata-rata nilai dengan kategori nilai sangat baik merupakan keberhasilan guru dalam melaksanakan pembelajaran di MA Al-Mubarak Marisa Kabupaten Pohuwato. Hasil penilaian pra/perencanaan pembelajaran pada siklus II akan diuraikan pada tiap aspek penilaian pra pembelajaran menunjukkan bahwa hasil penilaian kemampuan melaksanakan pembelajaran mencapai nilai rata-rata 83,70 dengan kategori baik, berarti dapat menunjukkan bahwa kemampuan guru kelas di MA AlMubarak Marisa Kabupaten Pohuwato dalam melaksanakan pembelajaran berkategori baik. Nilai rata-rata tersebut mengalami peningkatan 13,59\%. Dari jumlah keseluruhan guru, 5 guru di antaranya atau $83 \%$ termasuk dalam kategori baik dengan nilai antar 75 - 90, sedangkan 1 guru atau $17 \%$ termasuk dalam kategori cukup. Masih terdapatnya tingkat kemampuan guru berkategori cukup tersebut disebabkan berbagai hal, salah satu di antaranya adalah guru yang bersangkutan belum menguasai kelas dengan baik, selam PBM siswa saling berbicara sendiri dan kurang memperhatikan guru. Hasil penilaian pelaksanaan pembelajaran pada siklus II akan diuraikan pada tiap aspek penilaian pelaksanaan pembelajaran.

Hasil observasi siklus II dalam penelitian ini adalah pengamatan terhadap aktivitas guru dan siswa dalam KBM yang dilakukan oleh supervisor. Pengambilan data observasi dilakukan selama proses pelaksanaan pembelajaran di MA Al-Mubarak Marisa Kabupaten Pohuwato. Pengambilan data observasi ini bertujuan untuk memotret aktivitas guru dan siswa dalam proses KBM. Obyek sasaran yang diamati dalam observasi ini, meliputi 9 perilaku, yaitu: (1) pra pembelajaran; (2) pembukaan pembelajaran; (3) penguasaan materi pelajaran; (4) pendekatan/strategi pembelajaran; (5) pemanfaatan sumber belajar/media pembelajaran; (6) pembelajaran yang memicu dan memelihara keterlibatan siswa; (7) penilaian proses dan hasil belajar; (8) penggunaan bahasa, dan (9) menutup pelajaran. Berdasarkan hasil pengamatan pelaksanaan pembelajaran siklus II bahwa pelaksanaan pembelajaran di MA Al-Mubarak Marisa Kabupaten Pohuwato dalam kategori baik dengan skor nilai 88,66. Hasil pengamatan tersebut dapat dikatakan telah mengalami peningkatan sebesar 8 persen dari hasil pengamatan yang dilakukan pada siklus I.

Berdasarkan catatan pengamat pada siklus II terdapat beberapa perubahan perilaku guru antara lain: (1) pengajaran dimulai tepat waktu; (2) tidak terdapat guru yang sering menginggalkan ruang kelas; (3) terdapat perbaikan dalam pelaksanaan pembelajaran. Dari hasil observasi siklus II terlihat bahwa sudah ada perubahan yang lebih profesional guru kelas dari perilaku negatif pada siklus I menjadi perilaku positif pada siklus II, terbukti adanya peningkatan nilai rata-rata, baik nilai pra pembelajaran sebesar $12,35 \%$ serta peningkatan skor pengamatan sebesar $8 \%$. Berdasarkan catatan pengamatan siklus 
II dapat disimpulkan dari jumlah guru seluruhnya telah terjadi peningkatan sikap profesionalnya

\section{Pembahasan}

Pembahasan hasil penelitian didasarkan pada hasil pra siklus, hasil tindakan siklus I dan hasil tindakan siklus II. Penelitian tindakan sekolah ini dilaksanakan melalui 2 tahap, yaitu siklus I dan siklus II. Pembahasan hasil penelitian tersebut terdiri dari penilaian pra pembelajaran yang meliputi 5 aspek, yaitu: (1) pra pembelajaran; (2) pembukaan pembelajaran; (3) penguasaan materi pelajaran; (4) pendekatan/strategi pembelajaran; (5) pemanfaatan sumber belajar/media pembelajaran; (6) pembelajaran yang memicu dan memelihara keterlibatan siswa; (7) penilaian proses dan hasil belajar; (8) penggunaan bahasa, dan (9) menutup pelajaran.

Kegiatan tindakan dilakukan sebelum tindakan siklus I. hal ini dilakukan dengan tujuan untuk mengetahui gambaran kondisi awal kemampuan guru sebelum mengikuti siklus I. Setelah melaksanakan kegiatan, menganalisis, peneliti melakukan tindakan siklus I dan siklus II.

Dalam penelitian ini peneliti dibantu oleh kepala sekolah untuk melakukan observasi. Pada hari berikutnya sesuai dengan jadwal mengajar masing-masing guru dilakukan supervisi kunjungan kelas untuk menilai kemampuan guru dalam melaksanakan pembelajaran. Semua kegiatan tersebut dilakukan hingga dua kali, yaitu siklus I dan siklus II pada tempat yang sama. Pada akhir kegiatan dilakukan penelitian pra pembelajaran.

Hasil penilaian pra pembelajaran siklus I dengan nilai rata-rata mencapai 80,78 atau dalam kategori baik karena berada dalam rentang nilai $75-90$. Hasil tersebut sudah memenuhi target nilai rata-rata pada siklus I yaitu 75 . Nilai rata-rata tersebut diakumulasikan dari beberapa aspek penilaian. Pada aspek perumusan tujuan pembelajaran sebesar 88,8 termasuk kategori baik. Hal ini dikarenakan guru sudah memahami rumusan tujuan pembelajaran. Pada aspek penjabaran materi nilai rata-rata sebesar 79,0 termasuk dalam kategori baik, karena guru sudah dapat memilih dan mengorganisasikan materi ajar. Aspek alat/bahan pelajaran nilai rata-rata sebesar 72,2 dalam kategori cukup, dalam hal ini guru belum maksimal terhadap pemilihan sumber belajar/materi pelajaran. Aspek langkah-langkah PBM nilai rata-rata sebesar 75,0 termasuk dalam kategori baik berarti guru sudah dapat menentukan langkah-langkah PBM temasuk pemilihan metode mengajar yang sesuai dengan tujuan pembelajaran, materi dan karekteristik siswa. Aspek penilaian mencapai nilai rata-rata 92 dalam kategori sangat baik terutama dalam aspek ini guru memahami tentang penilaian hasil belajar secara lengkap yang meliputi: kisi-kisi soal, kunci jawaban, norma penilaian. Hasil penilaian pra pembelajaran pada siklus II sudah mencapai nila rata-rata sebesar 91,17 dengan hasil sangat baik. Pencapaian nilai tersebut berarti sudah melampaui target yang telah ditentukan, dengan demikian tindakan siklus III tidak perlu dilakukan. Rencana pembelajaran yang telah dilaksanakan penilaiannya, pada hari berikutnya dipakai sebagai pedoman dalam melaksanakan pembelajaran di kelas untuk mengetahui kemampuan guru dalam melaksanakan pembelajaran

Berdasarkan rekapitulasi pelaksanaan pembelajaran siklus I dengan nilai rata-rata 71,35 termasuk dalam kategori cukup, karena berada dalam rentang nilai $55-74$. Hasil tersebut belum dapat mencapai target nilai yang diharapkan yaitu 75 . Nilai rata-rata 
tersebut diakumulasikan dari beberapa aspek penilaian. Pada aspek pra pembelajaran sebesar 78,3 termasuk dalam kategori baik, dalam hal ini guru sudah melaksanakan kegiatan pra pembelajaran yang meliputi pemeriksaan ruang, alat, media, siswa dengan baik. Aspek pembukaan pembelajaran sebesar 90,00 termasuk dalam kategori baik, berarti guru sudah melaksanakan pembukaan pembelajaran dnngan melakukan apresiasi, menyampaikan tujuan kompetensi yang akan dicapai dengan baik. Aspek penguasaan materi pembelajaran sebesar 71,60 termasuk dalam kategori cukup, berarti kemampuan guru dalam penguasaan materi pembelajaran cukup baik. Aspek pendekatan/strategi pembelajaran sebesar 72,22 termasuk dalam kategori cukup, hal ini guru dalam menggunakan strategi pembelajaran cukup baik. Aspek pemanfaatan sumber belajar/media pembelajaran sebesar 63,33 termasuk dalam kategori cukup, berarti guru dalam memanfaatkan sumber/media pembelajaran cukup baik. Aspek pembelajaran yang memicu keterlibatan siswa dalam pembelajaran sebesar 74,60 termasuk dalam kategori baik, berarti guru sudah baik dalam memicu keterlibatan siswa dalam pembelajaran. Aspek penilaian proses dan hasil belajar sebesar 63,30 termasuk dalam kategori cukup, dalam hal ini melaksanakan penilaian proses dan hasil belajar cukup baik. Aspek penggunaan lisan nilai rata-ratanya sebesar 74,44 termasuk dalam kategori baik, berarti guru sudah menggunakan bahasa lisan dan bahasa tulisan dengan baik. Aspek penutup pembelajaran nilai rata-ratanya 50,00 termasuk dalam kategori kurang, pada siklus ini guru belum mengakhiri pembelajaran dengan bik, hal ini dikarenakan pembagian alokasi waktu yang kurang sehingga kehabisan waktu sebelum memberi rangkuman/refleksi dan tindak lanjut. Hasil penilaian pelaksanaan pembelajaran siklus II diperoleh nilai rata-rata sebesar 83,70 termasuk dalam kategori baik karena berada pada rentang nilai 75 - 90 . Pencapaian nilai tersebut berarti sudah memenuhi target yang telah ditentukan, dengan demikian tindakan siklus III tidak perlu dilakukan.

Pada aspek pra pembelajaran siklus II mencapai nilai 90,00 termasuk dalam kategori baik dan terjadi peningkatan 11,7 \% dari siklus I dengan baik. Aspek pembukaan pembelajaran siklus II mencapai nilai rata-rata 93,33 termasuk dalam kategori sangat baik dan terjadi peningkatan 3,33 \% dari siklus I karena guru melaksanakan pembukaan pembelajaran dengan sangat baik. Aspek penguasaan materi pembelajaran pada siklus II mencapai nilai rata-rata 81,60 termasuk dalam kategori baik dan terjadi peningkatan 10 $\%$ dari siklus I, menunjukkan bahwa guru menguasai materi ajar dengan baik. Aspek pendekatan/strategi pembelajaran siklus II mencapai nilai rata-rata 81,10 termasuk dalam kategori baik dan terjadi peningkatan $8,88 \%$ dari siklus I. Hal ini terjadi karena guru dalam penggunaan pendekatan/strategi pembelajaran sudah baik. Aspek pemanfaatan sumber/media pembelajaran siklus II mencapai rata-rata 80,00 termasuk dalam kategori baik dan terjadi peningkatan 16,67 \% dari siklus I, karena guru memanfaatkan sumber/media pembelajaran dengan baik. Aspek pembelajaran yang memicu dan memelihara ketertiban siswa mencapai nilai rata-rata 84,00 termasuk dalam kategori baik dan terjadi peningkatan 9,4\% dari siklus I, karena guru melaksanakan pembelajaran yang memicu dan memelihara ketertiban siswa dengan baik. Aspek penilaian proses dan hasil belajar siklus II mencapai nilai rata-rata 83,3 termasuk dalam kategori baik, dan terjadi peningkatan 9,4\% dari siklus I karena guru telah melaksanakan penilaian proses dan hasil belajar siswa dengan baik. Aspek penggunaan bahasa siklus II mencapai nilai rata-rata 84,44 termasuk dalam kategori baik dan terjadi peningkatan sebesar $10 \%$ dari siklus I, karena guru menggunakan bahasa tulis dan bahasa lisan dengan baik dan lancar. Aspek 
penutupan pembelajaran siklus II mencapai nilai rata-rata sebesar 82,6 termasuk dalam kategori baik dan terjadi peningkatan $31 \%$ dari siklus I, peningkatan ini dikarenakan guru sudah melaksanakan penutupan pembelajaran, yaitu melakukan refleksi/rangkuman dan melaksanakan tindak lanjut dengan baik. Peningkatan nilai pra pembelajaran sebesar $11,96 \%$ dari pra siklus ke siklus I, sebesar 10,38 \% dari siklus I ke siklus II, sebesar 22,35 $\%$ dari pra siklus ke siklus II, yang diikuti dengan peningkatan nilai pelaksanaan pembelajaran sebesar 12,35 \% dari siklus I ke siklus II seperti yang tersebut pada tabel 15 dapat menunjukkan adanya peningkatan kemampuan sikap profesionalisme guru dalam pelaksanaan pembelajaran.

Berdasarkan data pada lembar pengamatan siklus I dan siklus II, maka hasil pengamatan pelaksanaan kunjungan kelas dan pengamatan pelaksanaan pembelajaran siklus I dengan skor 80,66 termasuk dalam kategori baikdan hasil pengamatan pada siklus II mencapai nilai 88,66 termasuk dalam kategori baik, berarti terjadi peningkatan sebesar 8 dari siklus I ke siklus II. Berdasarkan dari serangkaian analisis data pelaksanaan kunjugan kelas untuk mengetahui profesionalisme guru dalam melaksanakan pembelajaran, telah terjadi perubahan perilaku guru yang positif, maka menunjukkan tingkat profesionalisme guru dalam pelaksanaan pembelajaran. Hasil penilaian pra pembelajaran yang cenderung meningkat diikuti dengan hasil penilaian pelaksanaan pembelajaran yang meningkat pula, ini menunjukkan adanya peningkatan profesionalisme guru dalam melaksanakan pembelajaran. Dengan demikian dapat disimpulkan bahwa dengan adanya Supervisi melalui kunjungan kelas dapat membantu guru dalam meningkatkan profesionalisme guru dalam pelaksanaan pembelajaran sehingga pada akhirnya dapat meningkatkan kualitas KBM yang baik dan menyenangkan.

\section{PENUTUP}

Profesionalisme guru dalam melaksanakan pembelajaran di MA Al-Mubarak Marisa Kabupaten Pohuwato setelah Supervisi melalui kunjungan kelas dalam kategori baik. Hal ini dapat dibuktikan dengan melalui hasil penilaian pelaksanaan pembelajaran pada siklus I mencapai nilai rata-rata 71,35 termasuk dalam kategori baik, kemudian pada siklus II mencapai nilai rata-rata 83,70 termasuk dalam kategori baik. Dengan demikian terjadi peningkatan pelaksanaan pembelajaran sebesar 12,35\%.

Guru MA Al-Mubarak Marisa Kabupaten Pohuwato setelah disupervisi melalui kunjungan kelas pra pembelajran yaitu kemampuan menyusun perencanaan pembelajaran yang sekaligus dapat mengalami peningkatan kemampuan melaksanakan pembelajaran. Peningkatan kemampuan guru tersebut dapat dibuktikan dari hasil penilaian pra pembelajaran pra siklus menunjukkan rata-rata 68,82 dan pada siklus I meningkat sebesar $11,96 \%$ dengan nilai rata-rata 80,78, kemudian pada siklus II meningkat lagi sebesar 10,38 \% menjadi 91,17 dengan kategori sangat baik. Peningkatan kemampuan guru dalam pra pembelajaran/perencanaan pembelajaran tersebut sekaligus diikuti dengan peningkatan kemampuan guru dalam melaksanakan pembelajaran pada siklus I mencapai nilai sebesar 71,35 dan pada siklus II mencapai nilai rata-rata sebesar 83,70, maka terjadi peningkatan sebesar 12,35\%. Dengan demikain dapat disimpulkan bahwa melalui kegiatan Supervisi dengan kunjungan kelas dan meningkatakan profesionalisme guru dalam melaksanakan pra pembelajaran/perencanaan pembelajaran dan dapat 
mengingkatkan kemampuan melaksanakan pembelajaran di MA Al-Mubarak Marisa Kabupaten Pohuwato

Berdasarkan pada kesimpulan hasil penelitian tersebut peneliti memberikan saran bahwa Sekolah hendaknya dapat mempromosikan kegiatan supervisi/kunjungan kelas untuk semua guru setiap semester, sehingga semua guru dapat menyusun perencanaan pembelajaran. Di samping itu dapat menumbuhkan motivasi guru terhadap penyusunan administrasi pembelajaran, mengingat semua skenario pembelajaran tercantum pada rencana pembelajaran. Dengan demikian guru yang melaksanakan pembelajaran selalu berpedoman pada rencana pembelajaran.

\section{DAFTAR PUSTAKA}

Badan Standar Nasional Pendidikan(2006) Naskah Akademik Tentang Standar Pengawas Satuan Pendidikan, Direktorat Pendidikan, Jakarta . ( 2007 ), Standar Isi, Direktorat Pendidikan, Jakarta (2007), Standar proses, Direktorat Pendidikan, Jakarta

Depdikbud (1998) Keputusan Menteri Negara Pendayagunaan Aparatur Negara Tentang Jabatan Fungsional Pengawas Sekolah dan Angka Kreditnya, Dirjen Pendasmen, Jakarta

Depdiknas (2001) Kamus Besar Bahasa Indonesia, Balai Pustaka . Jakarta

Departemen Pendidikan Nasional. (2004). Penilaian Kelas. Jakarta: Badan Penelitian dan Pengembangan Pusat Kurikulum.

Departemen Pendidikan Nasional. (2006). Panduan Penyusunan Kurikulum Tingkat Satuan Pendidikan. Jakarta: Pusat Kurikulum Badan Penelitian dan Pengembangan.

Departemen Pendidikan Nasional (2008). Pedoman Penyusunan Portofolio. Jakarta: Direktorat Jenderal Pendidikan Tinggi 
AKSARA: Jurnal Ilmu Pendidikan Nonformal

P-ISSN 2407-8018 E-ISSN 2721-7310 DOI prefix $\underline{10.37905}$

Volume 07, (03) September 2021

http://ejurnal.pps.ung.ac.id/index.php/Aksara

1134 AKSARA: Jurnal Ilmu Pendidikan Nonformal 